\title{
Observations of the mesospheric semi-annual oscillation (MSAO) in water vapour by Odin/SMR
}

\author{
S. Lossow ${ }^{1}$, J. Urban ${ }^{2}$, J. Gumbel ${ }^{1}$, P. Eriksson ${ }^{2}$, and D. Murtagh ${ }^{2}$ \\ ${ }^{1}$ Stockholm University, Department of Meteorology, Svante-Arrhenius-väg 12, 10691 Stockholm, Sweden \\ ${ }^{2}$ Chalmers University of Technology, Department of Radio and Space Science, Hörsalsvägen 11, 41296 Gothenburg, Sweden
}

Received: 19 March 2008 - Published in Atmos. Chem. Phys. Discuss.: 30 May 2008

Revised: 27 August 2008 - Accepted: 21 September 2008 - Published: 14 November 2008

\begin{abstract}
Mesospheric water vapour measurements taken by the SMR instrument aboard the Odin satellite between 2002 and 2006 have been analysed with focus on the mesospheric semi-annual circulation in the tropical and subtropical region. This analysis provides the first complete picture of mesospheric SAO in water vapour, covering altitudes above $80 \mathrm{~km}$ where previous studies were limited. Our analysis shows a clear semi-annual variation in the water vapour distribution in the entire altitude range between $65 \mathrm{~km}$ and $100 \mathrm{~km}$ in the equatorial area. Maxima occur near the equinoxes below $75 \mathrm{~km}$ and around the solstices above $80 \mathrm{~km}$. The phase reversal occurs in the small layer inbetween, consistent with the downward propagation of the mesospheric SAO in the zonal wind in this altitude range. The SAO amplitude exhibits a double peak structure in the equatorial region, with maxima at about $75 \mathrm{~km}$ and $81 \mathrm{~km}$. The observed amplitudes show higher values than an earlier analysis based on UARS/HALOE data. The upper peak amplitude remains relatively constant with latitude. The lower peak amplitude decreases towards higher latitudes, but recovers in the Southern Hemisphere subtropics. On the other hand, the annual variation is much more prominent in the Northern Hemisphere subtropics. Furthermore, higher volume mixing ratios during summer and lower values during winter are observed in the Northern Hemisphere subtropics, as compared to the corresponding latitude range in the Southern Hemisphere.
\end{abstract}

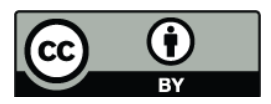

Correspondence to: Stefan Lossow (stefan.lossow@misu.su.se)

\section{Introduction}

The semi-annual oscillation (SAO) is the strongest mode of annual variability above $35 \mathrm{~km}$ altitude in the tropical region. This semi-annual variation has been first observed in temperature and zonal wind data in the 1960s (Reed and Rogers, 1962; Reed, 1966). The oscillation peaks around the stratopause with amplitudes of around $30 \mathrm{~m} \times \mathrm{s}^{-1}$ to $50 \mathrm{~m} \times \mathrm{s}^{-1}$ in the zonal wind speed. At the stratopause maximum westerly anomalies occur in April and October, while the maximum easterly anomalies can be observed in January and July. Subsequent measurements in the 1970s explored also altitudes above $60 \mathrm{~km}$ (Groves, 1972; Hirota, 1980). These measurements revealed that the semi-annual oscillation drops in amplitude above the stratopause and reaches a minimum around $65 \mathrm{~km}$ altitude. Higher up the SAO strengthens again, peaking a second time in the upper mesosphere. This leads to a distinction between the stratospheric (SSAO) and the mesospheric semi-annual oscillation (MSAO). The MSAO in the zonal wind has a similar amplitude and a phase which is approximately $180^{\circ}$ out of phase with respect to the SSAO variations (Hirota, 1980; Hamilton, 1982).

The amplitude of the SAO usually decreases with increasing latitude, but can recover in the subtropics depending on altitude. In this regard, the semi-annual oscillation exhibits a latitudinal asymmetry, with higher amplitudes in the Southern Hemisphere subtropics (Belmont and Dartt, 1973; Ray et al., 1998). Besides this latitudinal asymmetry, the semiannual oscillation shows also a seasonal asymmetry with stronger zonal wind variations during the first cycle, which starts with the easterly phase of the zonal wind in the Northern Hemisphere winter time (Delisi and Dunkerton, 1988; Garcia et al., 1997). 
Early attempts of explaining the semi-annual oscillation used the semi-annual variation of the solar radiation in the tropics as a possible cause (Webb, 1966). Further investigations showed rather soon that the solar forcing is not sufficient enough to create the SAO signature in the zonal wind (Meyer, 1970). The forcings that cause the easterly and westerly mean flow accelerations in the stratospheric SAO are rather different in nature. The easterly accelerations, on one hand, are due to the meridional advection of easterlies from the summer hemisphere across the equator (Meyer, 1970; Holton and Wehrbein, 1980). This effect occurs twice a year and peaks right after solstice. Another contribution to the easterly accelerations arises from the eddy momentum deposition by breaking planetary waves which have been ducted in the tropics. The westerly accelerations, on the other hand, are thought to be due to vertically propagating ultra-fast Kelvin waves and internal gravity waves that interact with the mean flow and deposit their momentum in the upper stratosphere. The relative portions of these two wave contributions has been discussed extensively (Hitchman and Leovy, 1988; Hamilton et al., 1995; Sassi and Garcia, 1997). The forcing of the mesospheric SAO is more uncertain. In general, the forcing is attributed to a broad spectrum of vertically propagating gravity and high-speed Kelvin waves, excited in the lower atmosphere. These waves are filtered by the zonal mean wind variations in the stratospheric SAO. This allows mainly waves with the opposite horizontal propagation direction with respect to the zonal wind direction to propagate further upward into the mesopause region, where these waves usually break. The filtering of these waves accounts for the phase shift between the stratospheric and mesospheric SAO (Dunkerton, 1982; Hitchman and Leovy, 1986).

The asymmetry between the two cycles of the semi-annual circulation is attributed to differences in the extratropical planetary wave forcing (Delisi and Dunkerton, 1988). The latitudinal asymmetry in the subtropics has been investigated in detail by Ray et al. (1998). According to their work no single forcing contributing to the SAO could be clearly connected to this asymmetry. The largest contribution arose instead from a different phasing of the maximum meridional advection between both hemispheres, which takes place later in the Southern Hemisphere.

The annual variation in the zonal wind influences also the annual distribution of atmospheric trace gases via induced meridional and vertical transport. The stratospheric SAO in water vapour has for example been observed by the MLS - Microwave Limb Sounder, Barath et al. (1993), and the HALOE - Halogen Occultation Experiment, Russell et al. (1993), instrument, both aboard the Upper Atmosphere Research Satellite (UARS) (Carr et al., 1995; Randel et al., 1998; Jackson et al., 1998). Signatures of the stratospheric SAO could be observed above $20 \mathrm{hPa}(\sim 27 \mathrm{~km})$. The analysis of these data sets showed a maximum amplitude of $0.2 \mathrm{ppmv}$ slightly below $1 \mathrm{hPa}(\sim 48 \mathrm{~km})$, with water vapour minima in February and August and maxima in
May and November, respectively. First weak indications of a semi-annual variation in mesospheric water vapour have been found by means of ground-based radiometer measurements in the mid-latitudes (Bevilacqua et al., 1989; Bevilacqua et al., 1990). Subsequent ground-based measurements in Lauder (New Zealand, $45.0^{\circ} \mathrm{S} / 169.7^{\circ} \mathrm{E}$ ) and Table Mountain (USA, $34.4^{\circ} \mathrm{N} / 117.7^{\circ} \mathrm{W}$ ) exhibited a clear semi-annual variation in the altitude range between $70 \mathrm{~km}$ and $80 \mathrm{~km}$ (Nedoluha et al., 1996). UARS/HALOE observations reported by Chandra et al. (1997) showed a strong SAO in water vapour in the equatorial region at $80 \mathrm{~km}$. Jackson et al. (1998) provided, to our knowledge, the only complete analysis of the mesospheric SAO in water vapour in the tropics and sub-tropics, up to an altitude of $80 \mathrm{~km}$. This analysis was based on HALOE measurements between the end of 1991 and the beginning of 1996. Compared to the SSAO, the MSAO exhibits a much stronger amplitude. Above the described SAO minimum at around $65 \mathrm{~km}$ the amplitude of the mesospheric SAO in water vapour increases rapidly, peaking at around $0.01 \mathrm{hPa}(\sim 80 \mathrm{~km})$ with more than a half ppmv. In accordance with the phase shift between the MSAO and the SSAO the annual water vapour distribution shows minima around April/May and October/November and maxima around January/February and July/August at about $80 \mathrm{~km}$. The rapid increase of SAO amplitude in the middle and upper mesosphere is mainly associated with the strong vertical gradient in water vapour in that altitude range. The UARS/HALOE water vapour measurements also showed the latitudinal asymmetry of the MSAO in the subtropics. In the Northern Hemisphere the SAO exhibited maximum amplitudes of about $0.25 \mathrm{ppmv}$ between $30^{\circ}$ and $35^{\circ}$ latitude, while in the same latitude band in the Southern Hemisphere the amplitudes showed peak values up to $0.6 \mathrm{ppmv}$ at an altitude close to $80 \mathrm{~km}$.

The Sub-Millimetre Radiometer - SMR, Frisk et al. (2003), aboard the Odin satellite passively scans thermal emission of several trace gases at the atmospheric limb [Murtagh et al., 2002]. Measurements at $557 \mathrm{GHz}$ provide global fields of mesospheric water vapour up to an altitude of $100 \mathrm{~km}$. In this paper we present water vapour observations in the tropics between 2002 and 2006. This data set has been analysed with particular focus on the mesospheric semi-annual circulation in water vapour. The Odin/SMR data provide a complete picture of the MSAO signal, with new insights in particular above $80 \mathrm{~km}$ altitude, where earlier studies were limited.

The outline of the paper is as follows. In Sect. 2 we give an general overview of the mesospheric water vapour observations by Odin/SMR and describe their quality and handling. The observations of the mesospheric SAO are presented and analysed in Sect. 3 and the results are discussed in Sect. 4. 

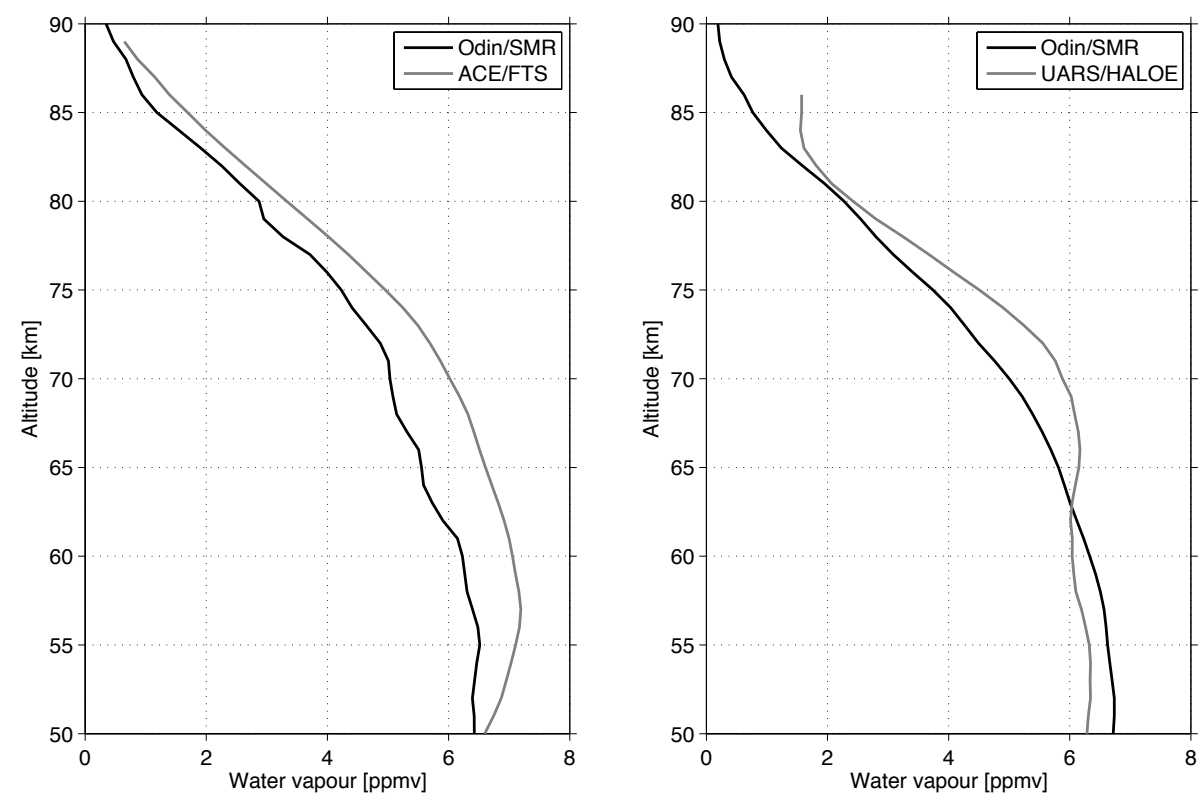

Fig. 1. Mesospheric water vapour comparison between the Odin/SMR Chalmers v2.1 retrieval and ACE/FTS (left panel) and UARS/HALOE (right panel) results respectively. The mean profiles represent measurements in the latitude band between $40^{\circ} \mathrm{S}$ and $40^{\circ} \mathrm{N}$ where the two instruments in question were separated by less than $5 \mathrm{~h}$ in time and $1000 \mathrm{~km}$ in space. The comparison with ACE/FTS and UARS/HALOE are based on 118 and 711 such events, respectively.

\section{Odin/SMR observations of mesospheric water vapour}

The Odin satellite has been launched on 20 February 2001 into a polar, sun synchronous and near-terminator orbit at an altitude of around $600 \mathrm{~km}$ and is orbiting the Earth about 15 times a day. One of two instruments carried aboard the satellite is the Sub-Millimetre Radiometer. This instrument is a heterodyne receiver employing a $1.1 \mathrm{~m}$ telescope in order to passively measure thermal emission at the atmospheric limb. It is composed of four tunable sub-millimetre radiometers covering several frequency bands between $486 \mathrm{GHz}$ and $581 \mathrm{GHz}$ and one millimetre radiometer measuring around $119 \mathrm{GHz}$. Two autocorrelators and one acousto-optical spectrograph can be attached to any of the radiometers to detect the received signal (Frisk et al., 2003).

\subsection{Measurements of the $557 \mathrm{GHz}$ band and its retrieval}

Odin/SMR measures several atmospheric emission lines of water vapour and its isotopes (Urban et al., 2007). Measurements of the $557 \mathrm{GHz}$ band have been performed on 4 days per month for the greater part of the Odin aeronomy mission. In April 2006 the measurement frequency was increased to 7 days per month. Since May 2007 these measurements are performed on about 11 days per month. These measurements are part of a stratosphere/mesosphere mode, where the atmospheric scans in general are ranging from $7 \mathrm{~km}$ to $110 \mathrm{~km}$ altitude. With a scanning velocity of $0.75 \mathrm{~km} \times \mathrm{s}^{-1}$ it takes more than two minutes to complete such a strato- sphere/mesosphere scan. Thus around 40 to 45 scans in total are performed per orbit. The integration time for a single tangent height measurement is approximately $1.85 \mathrm{~s}$. This time in combination with the spectrometer read-out times and the antenna characteristics determines the effective altitude resolution of the measurements, which is in the order of around $3 \mathrm{~km}$. The horizontal resolution in this altitude layer is characterised by the path length, which is about $400 \mathrm{~km}$. The horizontal sampling is given by the movement of the satellite, which is approximately $7 \mathrm{~km} / \mathrm{s}$ projected on the ground, and the time needed to perform the scan. Accordingly, the horizontal sampling is typically about one measurement per $1000 \mathrm{~km}$. For the measurements of the $557 \mathrm{GHz}$ band two of the four radiometers are used, either the 549A1 radiometer (covering $541 \mathrm{GHz}$ to $558 \mathrm{GHz}$ ) or the $555 \mathrm{~B} 2$ radiometer (covering $547 \mathrm{GHz}$ to $564 \mathrm{GHz}$ ), using in total three different frequency configurations. In either case autocorrelator number 1 is attached as the signal receiving spectrometer. The water vapour emission line covered by the measurements is centred at $556.936 \mathrm{GHz}$. This line is the strongest water vapour emission line in the entire microwave region. The line is optically thick in the centre up to approximately $70 \mathrm{~km}$ to $75 \mathrm{~km}$. Water vapour profiles can be retrieved from the spectra covering the altitude range between $40 \mathrm{~km}$ and $100 \mathrm{~km}$. The limiting factor on the lower altitude end is a combination of the limited bandwidth of the SMR instrument of $800 \mathrm{MHz}$ and the high optical thickness even in the line wings. The upper altitude limit is given by the signal-to-noise ratio and 
the volume mixing ratio of water itself. The retrieved altitude resolution is usually about $3 \mathrm{~km}$. The retrieval is done with a non-linear scheme using the Optimal Estimation Method (OEM) (Rodgers, 2000; Baron et al., 2001). The iteration scheme is based on a Newton and Levenberg-Marquardt method (Lautié et al., 2001). The typical statistical error of a single water vapour profile retrieved is between $5 \%$ and $15 \%$ below $80 \mathrm{~km}$. Above $90 \mathrm{~km}$ the statistical error can easily exceed $50 \%$. For more detailed information about the Odin/SMR mesospheric water vapour retrieval the reader is referred to Urban et al. (2007) and Lossow et al. (2007).

\subsection{Data quality}

The aim of the following quality assessment is to give a sincere characterisation of the mesospheric Odin/SMR water vapour data in the tropical and subtropical region. For the current study we use the official Odin/SMR retrieval version 2.1. The changes and status of this retrieval version for the mesospheric water have been described by Lossow et al. (2007). The quality of the retrieval version 2.1 level-2 data on the global scale has been assessed by a comparison to correlative satellite measurements performed by the Fourier Transform Spectrometer (FTS) instrument aboard the Canadian ACE - Atmospheric Chemistry Experiment, Bernath et al. (2005), satellite. ACE/FTS measures extinction spectra in the mid-infrared, using the rather precise solar occultation technique. The water vapour profiles have been retrieved using the ACE/FTS retrieval version 2.2 (Boone et al., 2005). The results of mesospheric ACE/FTS water vapour retrieval have already been compared to the EOS MLS Earth Observing System Microwave Limb Sounder, Waters et al. (2006) instrument aboard the Aura satellite, showing a very good agreement with deviations of less than $5 \%$ below $85 \mathrm{~km}$ (Lambert et al., 2007). The comparison of the mesospheric water vapour retrievals between Odin/SMR and ACE/FTS exhibits on the global perspective a dry bias of the SMR data in the entire altitude region (Carleer et al., 2008). The observed behaviour is very similar in the latitude range between $40^{\circ} \mathrm{S}$ and $40^{\circ} \mathrm{N}$, which we implement in this study. This can be seen in the left panel of Fig. 1, which shows a comparison of mean profiles based on 118 events in this latitude range where Odin/SMR and ACE/FTS measurements were not separated by more than $5 \mathrm{~h}$ in time and $1000 \mathrm{~km}$ in space. At $50 \mathrm{~km}$ Odin $/ \mathrm{SMR}$ exhibits $0.2 \mathrm{ppmv}$ ( $\sim 3 \%$ deviation with respect to the mean of Odin/SMR and ACE/FTS) less water vapour than ACE/FTS. The dry bias increases above, peaking with $1.1 \mathrm{ppmv}(\sim 20 \%$ deviation) in the altitude range between $60 \mathrm{~km}$ and $70 \mathrm{~km}$. Above this altitude range the deviation decreases with altitude and between $80 \mathrm{~km}$ and $89 \mathrm{~km}$ (the uppermost altitude retrieved by ACE/FTS) the Odin/SMR dry bias is always below $0.5 \mathrm{ppmv}$ ( $\sim 20 \%-40 \%$ deviation).
The SAO analysis by Jackson et al. (1998) based on UARS/HALOE data is an important basis for the discussion of the Odin/SMR observations of the semi-annual oscillation (Sect. 4). Therefore, we have performed the same kind of comparison for the tropical and subtropical latitude region between these two instruments as we did with ACE/FTS before. The results of this comparison are shown in the right panel of Fig. 1. In this case we found 771 events of coincident measurements. Below $60 \mathrm{~km}$ the retrieved water vapour from Odin/SMR measurements is $0.3 \mathrm{ppmv}$ ( $\sim 5 \%$ deviation with respect to the mean of Odin/SMR and UARS/HALOE) higher as compared to UARS/HALOE. At $62 \mathrm{~km}$ altitude both instruments show the same amount of water vapour. Above this altitude the retrieved Odin/SMR water vapour shows a dry bias, similar as seen in the comparison with ACE/FTS. This bias maximises at around $72 \mathrm{~km}$ with $1.0 \mathrm{ppmv}$ ( $\sim 18 \%$ deviation) and above to about 0.3 ppmv ( $5 \%$ deviation) at $80 \mathrm{~km}$ altitude.

The large distance allowed between the coincident measurements might cause a bias in the comparisons if there is a significant offset in the average latitude between

the implemented measurements of the respective satellites. However, no such apparent offset in the average latitude can be found. In addition we repeated the comparisons with ACE/FTS and UARS/HALOE allowing only a maximum distance of $500 \mathrm{~km}$ between the coincident measurements. Applying this stricter criterion reduces the number of coincident measurements by about $70 \%$ in both cases. Nonetheless, changes are only small and the overall characteristics of the comparisons remain.

For the analysis of the semi-annual oscillation we expect in general no or only a very small influence of the dry bias of the SMR data set in the altitude range of interest. This conclusion is based on our idea to analyse the SAO signal as a temporal deviation around a mean state.

\subsection{Data set and its handling}

For the characterisation and analysis of the mesospheric semi-annual oscillation in water vapour we use measurements from Odin/SMR performed between 2002 and 2006. Only data taken by the frequency configuration "freqmode 19" has been implemented in this analysis. This frequency configuration employs the 549A1 radiometer and has been used continuously and most often throughout the Odin mission for the mesospheric water vapour measurements. Moreover, this configuration is the most optimised out of the three frequency configurations used for those measurements (see Sect. 2.1). We implement only profiles which have been flagged as usable for scientific analysis by the retrieval quality control. This quality control is based on different parameters, such as the convergence, the cost function of the retrieval (chi-square statistical analysis), the LevenbergMarquardt parameter (regularisation of the non-linear retrieval) and the retrieved pointing offset. From those profiles 


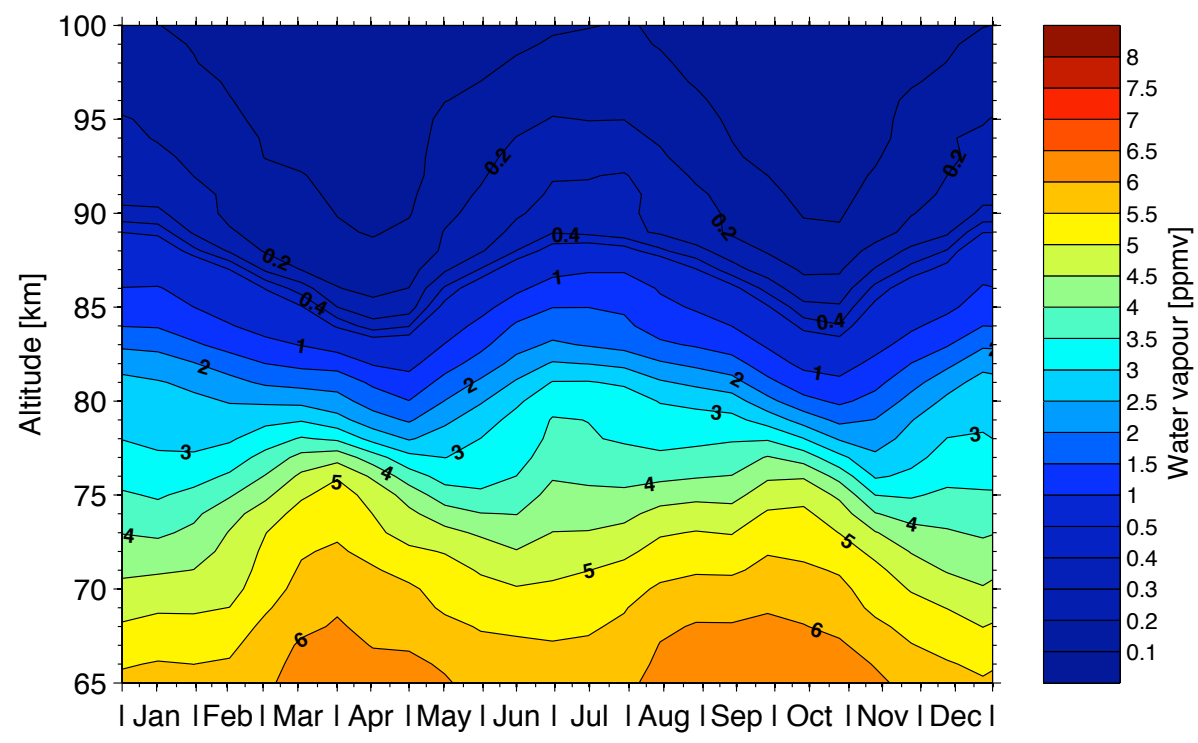

Fig. 2. The mean water vapour distribution observed by Odin/SMR in the equatorial region during the years 2002 to 2006 . Data from the latitude range between $10^{\circ} \mathrm{S}$ and $10^{\circ} \mathrm{N}$ have been included. The time grid is 15 days, while the single data points describe a 30 day mean.
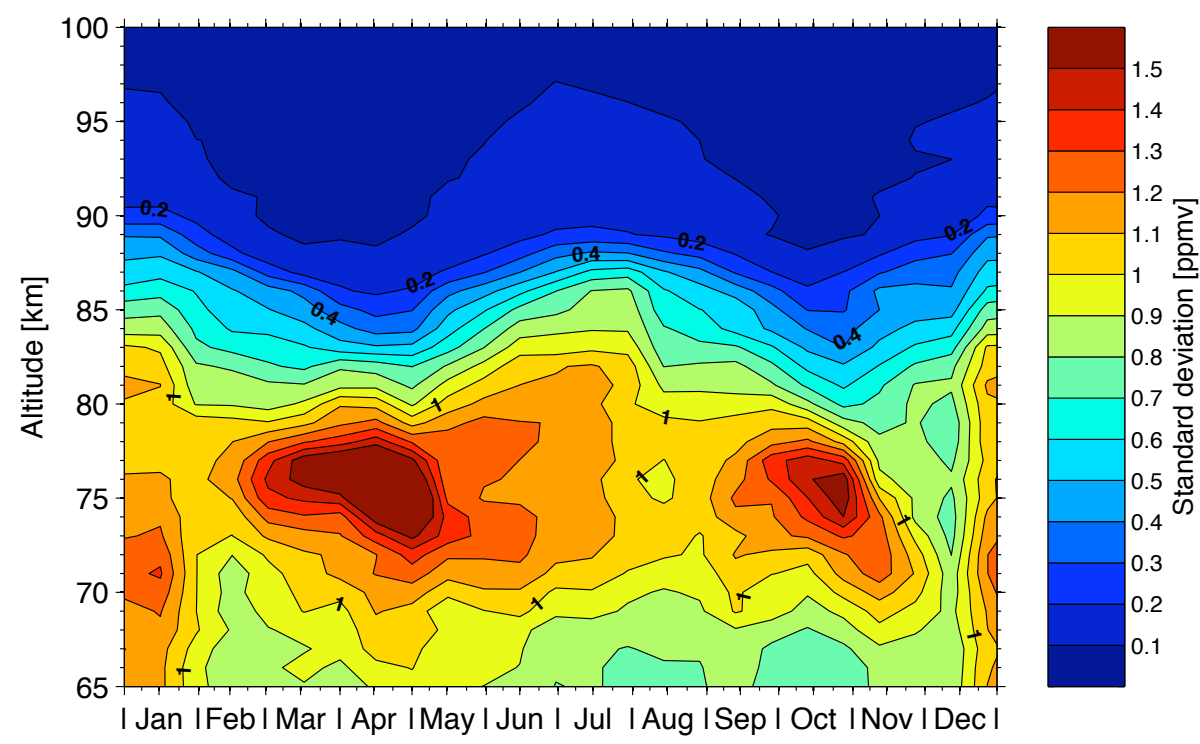

Fig. 3. The standard deviation corresponding to the mean water vapour distribution shown in Fig. 2.

only data are used, where the measurement shows a response of at least $70 \%$ in the retrieved values. This high measurement response ensures that the influence of the a priori information needed for an OEM retrieval is minimised.

Due to its sun-synchronous orbit Odin always performs measurements only at two distinct local times (LT) at a given latitude (one local time on the ascending node and a second local time on the descending node). In the equatorial and tropical region Odin takes measurements around 06:0007:00 LT and 18:00-19:00 LT. Thus, any given result would only represent the characteristics for these two local time ranges. In order to get general results the local time variation must be accounted for, which is determined by atmospheric tidal waves. Tidal contributions to the data set can be significant, especially in the upper mesosphere and lower thermosphere, and can influence the analysis of the semi-annual oscillation. In the tropical region the most prominent tide is the migrating diurnal tide, which propagates westwards following the apparent motion of the Sun (e.g Chapman and Lindzen, 1970; Forbes, 1995). This tide is mainly forced in 


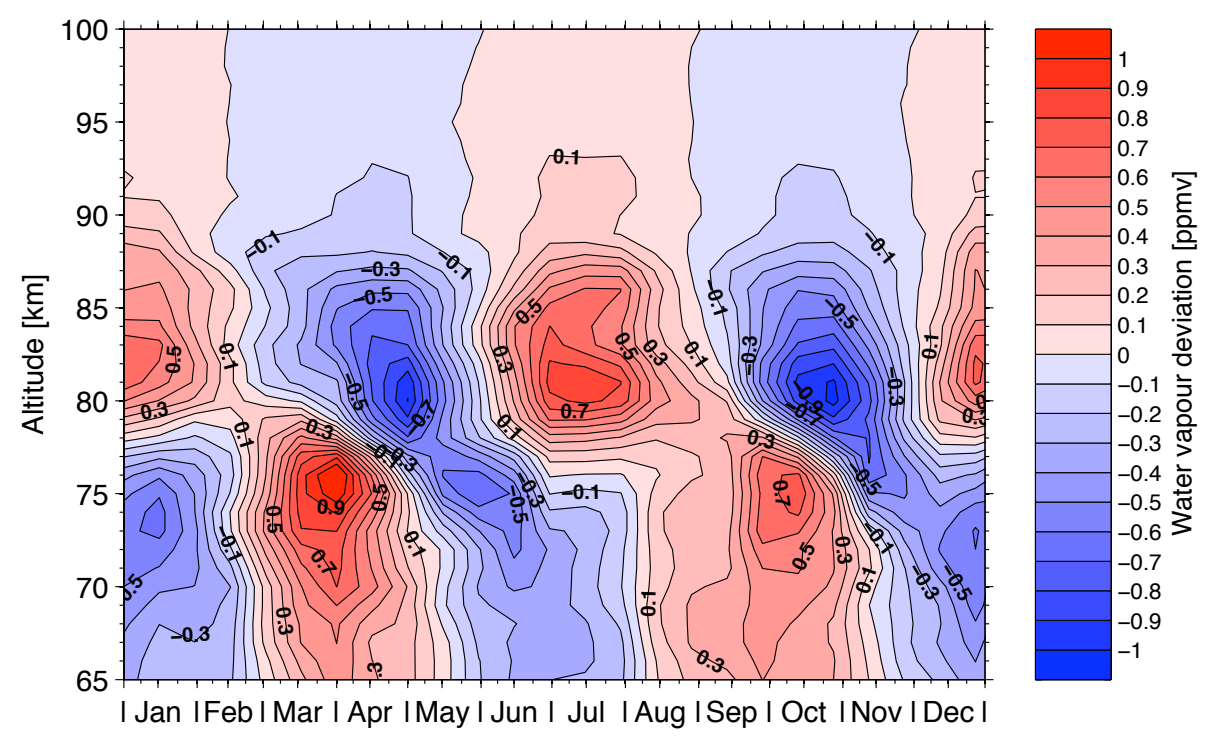

Fig. 4. The deviation of the mean water vapour distribution shown in Fig. 2 with respect to a 180 days running average of the mean distribution.

the troposphere by solar heating and exhibit, like the SAO, a semi-annual variation with peaks near the equinoxes (Vincent et al., 1988; Burrage et al., 1995; McLandress, 1997). In addition, a weaker migrating semi-diurnal tide and nonmigrating tides can be observed. Measurements of the tidal variation of water vapour in the altitude range of interest are very rare and reports in the literature are essentially nonexisting. Due to its sun-synchronous orbit, Odin measurements are not suitable to provide detailed information on the diurnal variation of water vapour. Similarly satellite-based solar occultation instruments have only a limited capability to extract the diurnal characteristics, since they only measure at sunset and sunrise. Data from ground-based radiometers usually needs to be integrated over $24 \mathrm{~h}$ in order to provide useful measurements at an altitude of $80 \mathrm{~km}$. Hence, for the time being, only models can give answers about the diurnal (tidal) variation of water vapour in the upper mesosphere and lower thermosphere. In our case we used data from WACCM - Whole Atmosphere Community Climate Model, Garcia et al. (2007), in order to estimate the most important tidal contributions in the tropics and subtropics due to the migrating diurnal and semi-annual tide. In the tropical region the maximum amplitude of the migrating diurnal tide is about 1 ppmv, while the migrating semi-diurnal tide reaches a maximum amplitude of $0.4 \mathrm{ppmv}$. The modelled tidal contributions as a function of latitude, local time, altitude and day of year have been subtracted from the individual water vapour profiles retrieved before any averaging. This correction does neither take into account non-migrating tides nor the interannual variation of migrating tides due to quasi-biennial oscillation (QBO, Baldwin et al. (2001) and references therein) (Burrage et al., 1995).
After the tidal correction has been applied the data set has been averaged onto a 15 day time grid, where every grid point describes a mean of 30 days. Thus the single data points are not completely independent from each other in time. In the vertical the data have been interpolated onto a $1 \mathrm{~km}$ altitude grid. In order to describe the latitudinal dependence of the SAO the data have been averaged over a latitude range of 10 degrees using a 5 degree latitude grid. Hence, just as in the time domain, the single data points are not independent from each other in the latitude domain.

The amplitudes of the semi-annual and annual variation of the mesospheric water vapour distribution in the tropical and subtropical region are then determined by means of a wavelet analysis. In order to get general results we averaged over the time component of the global wavelet spectrum (Torrence and Compo, 1998). For this spectral analysis we have employed the whole time series between 2002 and 2006. A data gap in February 2006 has been filled by linear interpolation for the sake of convenience. In order to estimate the statistical significance of the determined amplitude we applied the jackknife method (Efron, 1979). The basic idea behind this method is to systematically recalculate the amplitude of the desired frequency components from altered time series, where in each case a different set of observations has been removed from the original time series. This procedure leads to a new data set of amplitudes, which can be used to estimate the standard deviation of the amplitude derived from the original time series. 


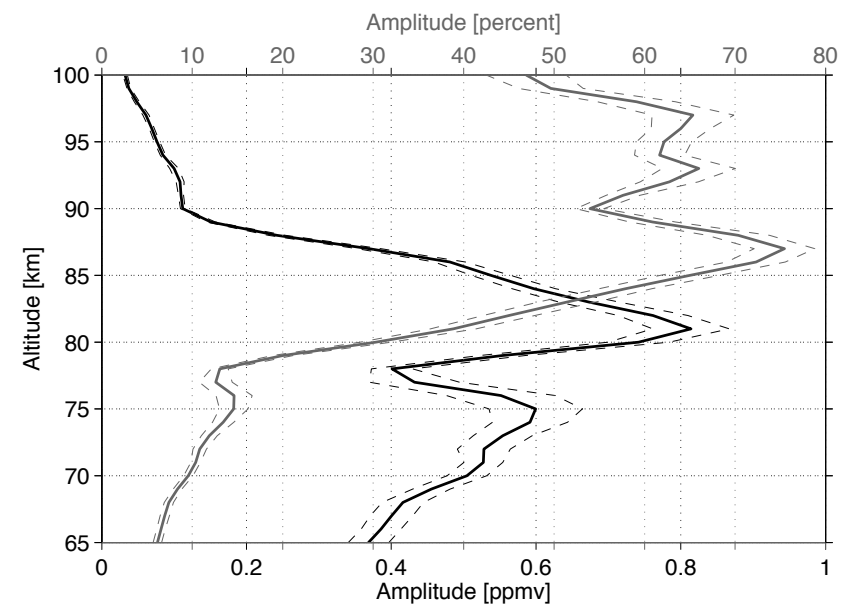

Fig. 5. The mean absolute (black, lower axis) and relative amplitude (grey, upper axis) of the semi-annual variation of the water vapour distribution between 2002 and 2006 as a function of altitude. The relative amplitude employs the mean profile derived from the annual distribution displayed in Fig. 2 as the reference. The dashed lines represent the error of the amplitude as determined by means of the jackknife method.

\section{Observations and results}

\subsection{Equatorial region $10^{\circ} \mathrm{S}-10^{\circ} \mathrm{N}$}

Figure 2 shows the mean annual water vapour distribution in the latitude range between $10^{\circ} \mathrm{S}$ and $10^{\circ} \mathrm{N}$ as measured by Odin/SMR for all years considered. At all altitudes a semi-annual variation of water vapour can be observed. In the upper altitude range above $80 \mathrm{~km}$ water vapour exhibits maxima at the end of December/beginning of January and in July. The minima occur in April and October. In the lower altitude range below $75 \mathrm{~km}$, on the other hand, the position of the maxima and minima is flipped with respect to the upper altitude domain. Maxima can be observed at the end of March/beginning of April and in October while the minima appear in December and at the turn of June and July. The transition between the these two different phase domains occurs in a rather thin layer between approximately $75 \mathrm{~km}$ and $80 \mathrm{~km}$.

The standard deviation of the mean water vapour distribution is given in Fig. 3, in order to give also an indication of the observed annual and inter-annual variability. The variability exhibits in general the same pattern as the mean water vapour distribution. The absolute highest variability can be observed at about $75 \mathrm{~km}$ around the equinoxes.

Figure 4 shows the deviation of the mean annual water vapour distribution shown in Fig. 2 with respect to a 180 days running average of this mean distribution. This figure shows more clearly the observed time shift of the water vapour extrema between $75 \mathrm{~km}$ and $80 \mathrm{~km}$. In addition these devia-

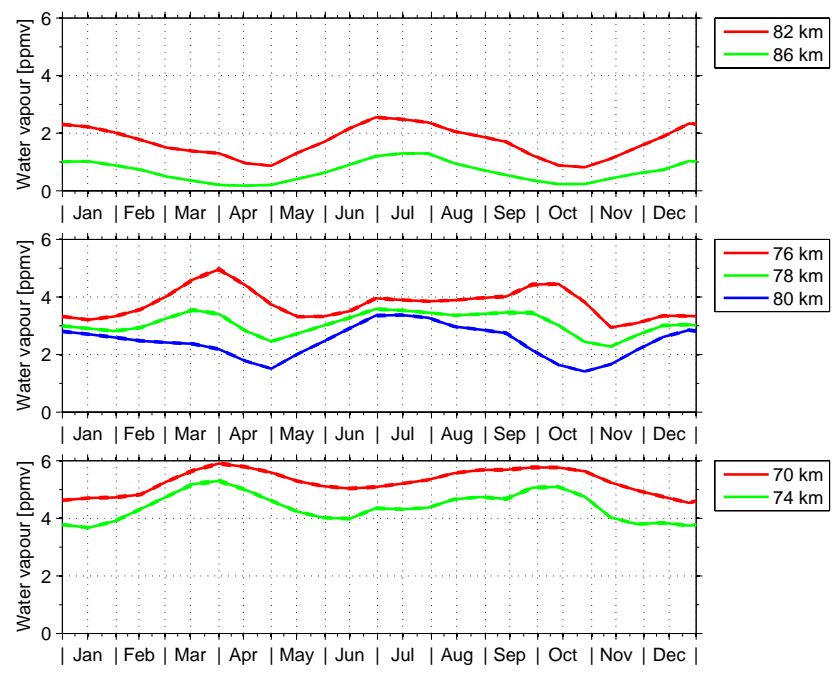

Fig. 6. Mean annual time series of water vapour in the equatorial area in three central altitude ranges. Lower panel: below $75 \mathrm{~km}$ (below the lower SAO amplitude peak). Middle panel: between $76 \mathrm{~km}$ and $80 \mathrm{~km}$. Upper panel: above $81 \mathrm{~km}$ (above the upper SAO amplitude peak). The dashed lines represent the error bar of the single time series.

tions provide also a first indication of the amplitude of the semi-annual variation of water vapour. The absolute maximum amplitudes occur in two layers, one at about $75 \mathrm{~km}$ and the other one at around $81 \mathrm{~km}$, clearly exceeding $0.5 \mathrm{ppmv}$. Above $90 \mathrm{~km}$ the absolute water vapour deviations are small, just like the absolute water vapour volume mixing ratio itself. Below $75 \mathrm{~km}$ the absolute deviations decrease with decreasing altitude.

The absolute amplitude of the semi-annual variation of the water vapour distribution as a function of altitude is given by the black line in Fig. 5 (using the lower axis). As already evident from Fig. 4, the semi-annual variation of the mesospheric water vapour distribution peaks at two distinct altitudes in the equatorial region, namely at $75 \mathrm{~km}$ with around $0.6 \mathrm{ppmv}$ and at $81 \mathrm{~km}$ with around $0.8 \mathrm{ppmv}$. In the altitude region in-between, where also the phase shift of the semiannual variation occurs, a significant minimum can be observed. The amplitude of the semi-annual component drops here to $0.4 \mathrm{ppmv}$ at $78 \mathrm{~km}$ altitude. In the altitude range between $81 \mathrm{~km}$ and $90 \mathrm{~km}$ the SAO amplitude decreases rather strongly, similar to the absolute amount of water vapour. At $90 \mathrm{~km}$ altitude the amplitude of the semi-annual component is somewhat more than $0.1 \mathrm{ppmv}$. Above $90 \mathrm{~km}$ the amplitude decreases much slower with altitude. It is also notable that we do not observe a distinct altitude where the minimum amplitude of the semi-annual variation between the stratopause and the higher mesosphere occurs. The minimum amplitude we observe is in the order of $0.30 \mathrm{ppmv}$ to $0.35 \mathrm{ppmv}$ and spans over the altitude range between $50 \mathrm{~km}$ and $63 \mathrm{~km}$ (not shown here). 
Expressed in relative terms the semi-annual variation peaks above $80 \mathrm{~km}$ as shown by the grey line in Fig. 5 (using the upper axis). As reference we used the mean profile derived from the annual distribution displayed in Fig. 2. Two maxima can be observed above $80 \mathrm{~km}$, where the relative amplitude of semi-annual variation is up to $60 \%$ and more. One maximum occurs close to $87 \mathrm{~km}$ and a second one is spread out over the altitude range between approximately $93 \mathrm{~km}$ and $97 \mathrm{~km}$. These two maxima are separated by a minimum at $90 \mathrm{~km}$. At this altitude the amplitude of the semi-annual variation stands for somewhat more than $50 \%$ of the total water vapour amount. Below $85 \mathrm{~km}$ the relative amplitude decreases strongly with decreasing altitude. At $78 \mathrm{~km}$ the relative amplitude of the semi-annual variation is less than $15 \%$. Even below this altitude the amplitude continues to decrease with decreasing altitude, but only slightly.

A comparison with the data where the tidal contributions were not removed using WACCM revealed no significant differences with respect to the amplitude of the semi-annual component of the mesospheric water vapour variation.

Figure 6 gives a detailed view on some of the mean annual water vapour time series in the three key altitude ranges. The lower panel shows time series below $75 \mathrm{~km}$. The altitude range between the two amplitude maxima of the semi-annual variation, $76 \mathrm{~km}$ and $80 \mathrm{~km}$, where also the phase shift of the SAO occurs, is given in the middle panel. Time series from above $81 \mathrm{~km}$ are shown in the upper panel. In the altitude range below $75 \mathrm{~km}$ the first annual minimum (starting in January) exhibits in general a lower water vapour concentration than the second one. On the contrary the first annual maximum tends to show slightly more water vapour with respect to the maximum in the Northern Hemisphere autumn. The second maximum appears to be "broader" in time. At $76 \mathrm{~km}$ a small bump can be observed at the end of June/beginning of July. This bump may be a very first indication of the phase change of the semi-annual variation occurring in the thin layer above. Two kilometres higher up the annual variation looks like as having rather three maxima than only two. One maximum occurs in March, one in December and a very broad one that is spread out between July and September. At $80 \mathrm{~km}$ altitude the phase shift of the semi-annual water vapour variation is almost complete. Above this altitude, in general more water vapour can be observed at the maximum in the middle of the year as compared to the maximum at the end of the year. As evident in Figs. 2 and 4, Fig. 6 clearly manifests that the phase of the semi-annual variation of water vapour below $75 \mathrm{~km}$ and above $81 \mathrm{~km}$ is not completely shifted by 180 degrees, since the corresponding extrema lie not perfectly on top of each other.

\subsection{Tropical and subtropical region $35^{\circ} \mathrm{S}-35^{\circ} \mathrm{N}$}

Two latitudinal cross section examples of the mean annual water vapour distribution are given in Fig. 7, covering the latitude range between $35^{\circ} \mathrm{S}$ and $35^{\circ} \mathrm{N}$. The lower panel shows the altitude of $75 \mathrm{~km}$ and the upper panel shows the altitude of $83 \mathrm{~km}$ respectively. At $75 \mathrm{~km}$ altitude, the water vapour maxima both in March/April and in September/October appear to be centred in the Southern Hemisphere at about $5^{\circ} \mathrm{S}$. From the centre of the maximum towards the mid-latitudes the amount of water vapour generally decreases and the strength of the semi-annual variation gets weaker. The water vapour distribution in the extra tropical mesosphere is dominated by an annual component. Maximum values occur during summer time and the minimum can be observed in winter. This behaviour is due to a gravity wave driven meridional circulation with an ascending branch over the summer hemisphere and downwelling motion over the winter hemisphere. Parts of this annual component become evident at latitudes higher than 25 degrees shown in Fig. 7. At those latitudes also clear inter-hemispheric differences can be noted. In comparison to its Southern Hemisphere counterpart the Northern Hemisphere summer exhibits higher water vapour concentrations. On the contrary less water vapour can be observed in the Northern Hemisphere winter than in the Southern Hemisphere winter.

The structure of the water vapour distribution at $83 \mathrm{~km}$ looks simpler than at $75 \mathrm{~km}$, since the water vapour extrema occur at the same time at all latitudes. The observed maxima in the tropical region could literally be described as the "tips of two tongues", originating as an equatorward extension of the extra-tropical summer water vapour maximum in each hemisphere. Similar to the conditions at $75 \mathrm{~km}$ seasonal inter-hemispheric differences can clearly be observed at the latitude higher than 25 degrees. In addition, looking for example at the 1.75 ppmv contour line it can be seen that this line extends from the Northern Hemisphere down to a latitude of about $20^{\circ} \mathrm{S}$ in the Northern Hemisphere summer. On the other hand, this contour line extends from the Southern Hemisphere only up to a latitude slightly north of the equator in the Southern Hemisphere summer. This observation can also be made, even if not so clear, using other contour lines. A similar behaviour can be observed roughly up to an altitude of $90 \mathrm{~km}$.

Figure 8 gives an overall picture of the latitude and altitude dependence of the amplitude of the semi-annual and annual variation of the mesospheric water vapour distribution. Above approximately $78 \mathrm{~km}$ the amplitude of the semi-annual variation exhibits nearly no latitude dependence within the latitude range between $35^{\circ} \mathrm{S}$ and $35^{\circ} \mathrm{N}$. The maximum amplitude can be observed at around $82 \mathrm{~km}$ at a latitude of circa $15^{\circ} \mathrm{N}$ exceeding $0.85 \mathrm{ppmv}$. This observation is not statistically significant, since the amplitude error determined by the jackknife method is also high. The same significance problem applies to amplitude maximum at $75 \mathrm{~km}$, which 


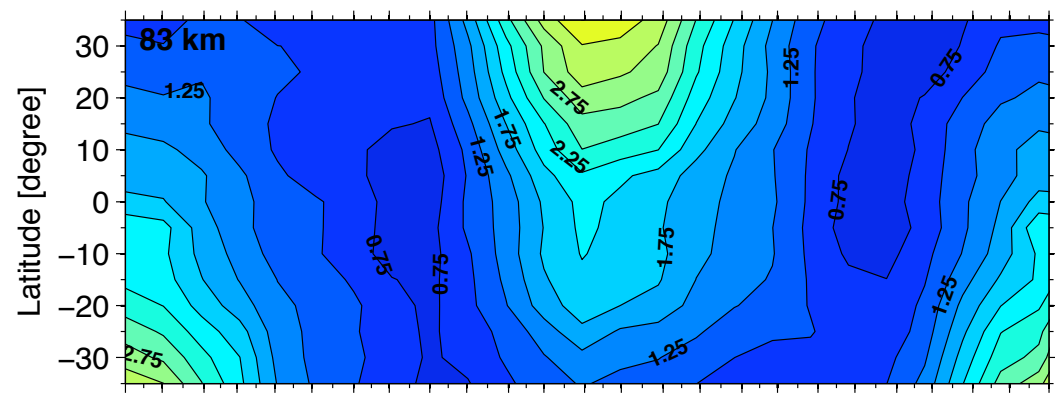

I Jan IFeb I Mar I Apr I May I Jun I Jul I Aug ISep I Oct INov I Dec I
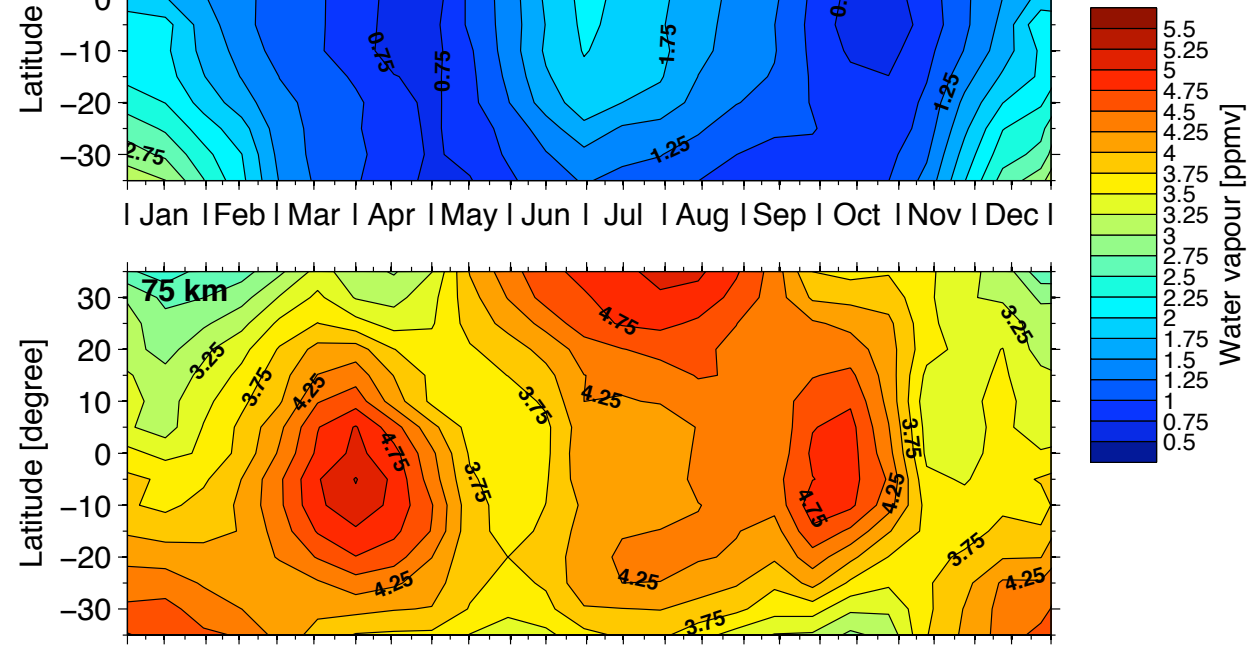

Fig. 7. Latitudinal cross section of the mean annual distribution of water vapour at $75 \mathrm{~km}$ (lower panel) and at $83 \mathrm{~km}$ (upper panel).

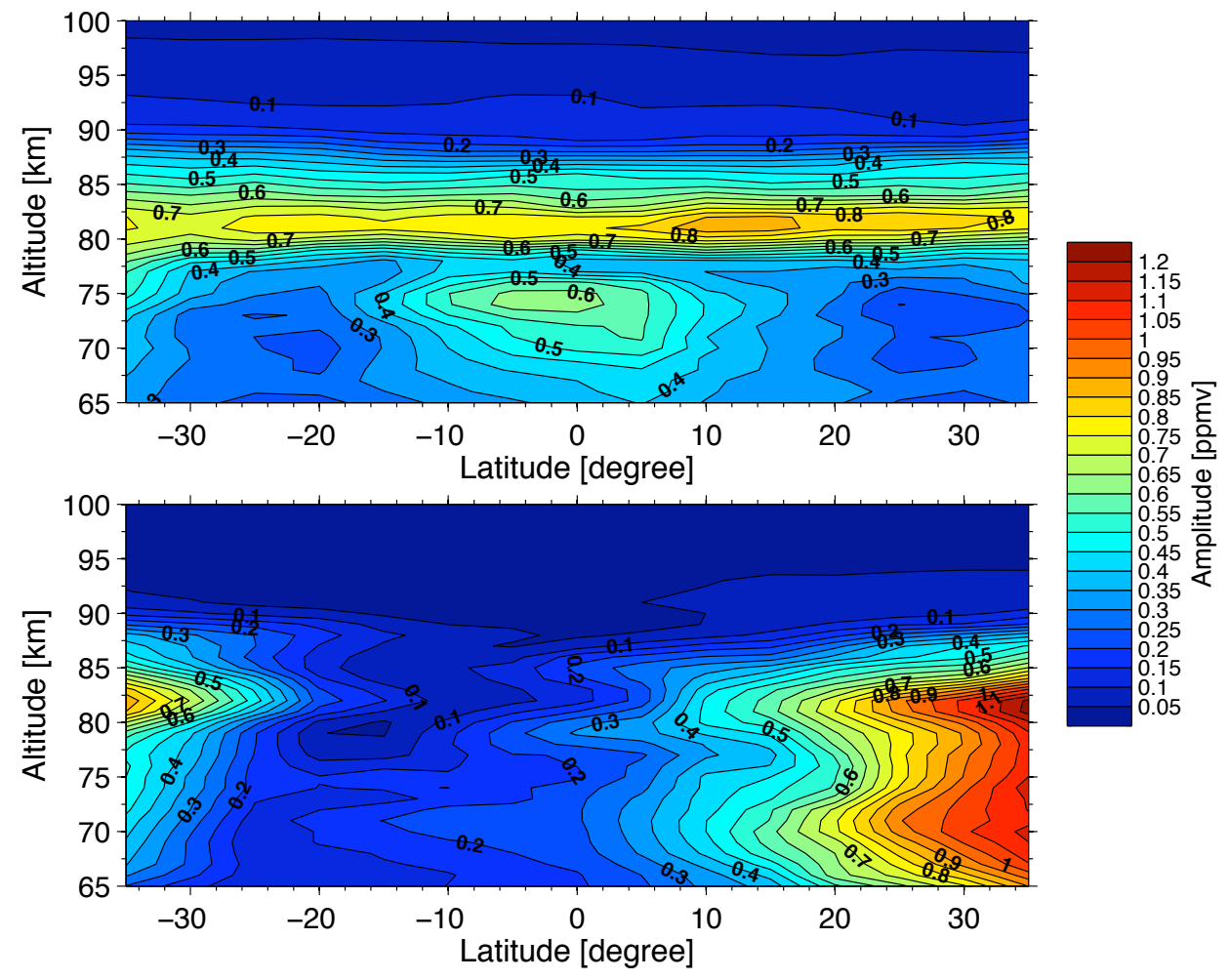

Fig. 8. Contours of the latitude - altitude dependence of the amplitude of the semi-annual (upper panel) and annual (lower panel) component of the mesospheric water vapour variation in time. 

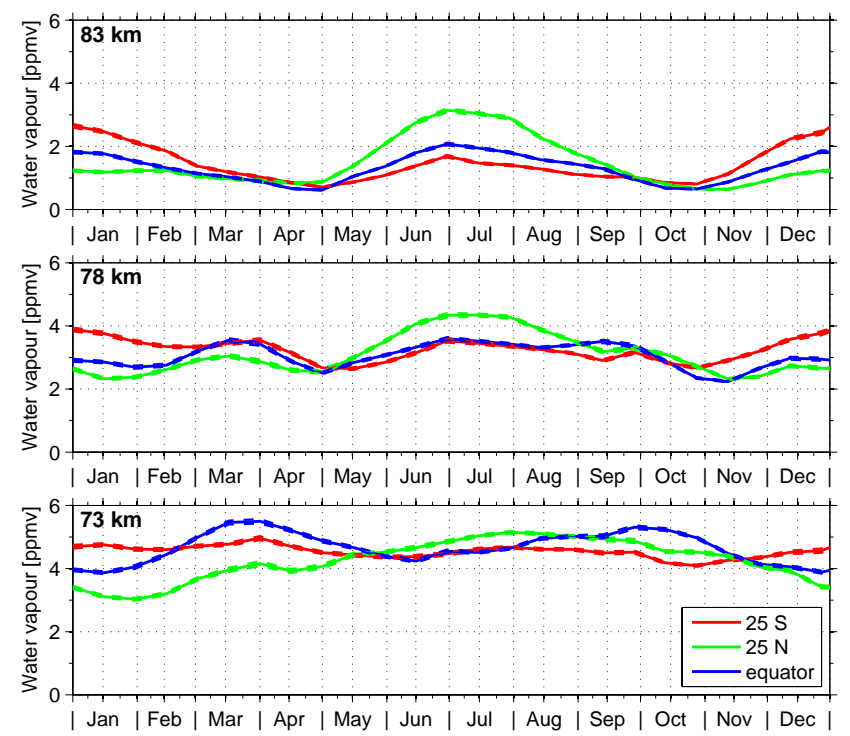

Fig. 9. Water vapour time series at $25^{\circ} \mathrm{N}$ (green), $25^{\circ} \mathrm{S}$ (red) and the equator (blue) at $73 \mathrm{~km}$ (lower panel), $78 \mathrm{~km}$ (middle panel) and $83 \mathrm{~km}$ (upper panel). The dashed lines describe the error bar of the time series.

appears to be slightly centred on the Southern Hemisphere. Towards higher latitudes the amplitude of the semi-annual water vapour variation decreases, reaching a minimum at around 25 degree latitude with approximately 0.25 ppmv. In the altitude range between $65 \mathrm{~km}$ and $75 \mathrm{~km}$ the amplitude increases again, but only in the Southern Hemisphere. This increase is rather strong especially at the higher altitudes where for example an amplitude of $0.5 \mathrm{ppmv}$ at $75 \mathrm{~km}$ can be observed at $35^{\circ} \mathrm{S}$.

The amplitude of the annual component of the variation of the mesospheric water vapour distribution reveals a clear inter-hemispheric difference with the minimum centred in the Southern Hemisphere in the latitude range between $5^{\circ} \mathrm{S}$ and $20^{\circ} \mathrm{S}$. The minimum amplitude here is rather constant with altitude, usually between $0.1 \mathrm{ppmv}$ and $0.15 \mathrm{ppmv}$, except for the uppermost altitudes above $90 \mathrm{~km}$. The strongest latitude dependence of the annual component in the Southern Hemisphere occurs in a layer between $80 \mathrm{~km}$ and $85 \mathrm{~km}$ where the amplitude increases up to more than $0.8 \mathrm{ppmv}$ at $35^{\circ} \mathrm{S}$. South of $30^{\circ} \mathrm{S}$ between $65 \mathrm{~km}$ and $90 \mathrm{~km}$ the amplitude of the annual water vapour variation is roughly comparable to the amplitude of the semi-annual variation. At lower southern latitudes the semi-annual variation is in contrast clearly the dominant variation in this altitude range. In the Northern Hemisphere the amplitude of the annual variation of the water vapour distribution increases rather strong towards the mid-latitudes, especially below $85 \mathrm{~km}$. At $35^{\circ} \mathrm{N}$ the amplitude exceeds $1 \mathrm{ppmv}$ in that altitude range. The transition from the semi-annual to the annual variation as the dominant contribution to the temporal variation of the wa- ter vapour distribution occurs at approximately $10^{\circ} \mathrm{N}$, concerning the altitude range between $65 \mathrm{~km}$ and $85 \mathrm{~km}$. Above $90 \mathrm{~km}$ the amplitude of the annual water vapour variation exhibits nearly no latitude dependency. At those altitude the semi-annual variation is stronger as the annual variation amplitude at all latitudes implemented in our analysis. In addition to semi-annual and annual variations described here we also found a small QBO and a 90 day time variation.

In Fig. 9 some examples of time series at $25^{\circ} \mathrm{N}$ (green) and $25^{\circ} \mathrm{S}$ (red) provide a more closer look at the two hemispheres and differences between them, as described in the last two figures, i.e. Figs. 7 and 8. Just for the sake of comparison we also included the time series at the equator (blue). The results are shown at $73 \mathrm{~km}$ (lower panel), $78 \mathrm{~km}$ (middle panel) and $83 \mathrm{~km}$ (upper panel). The time series at $73 \mathrm{~km}$ in the Northern Hemisphere exhibits clearly a dominating annual component of the water vapour variation. At $25^{\circ} \mathrm{S}$ the semi-annual variation is still the prevailing component. Like at the equator in both hemispheres the water vapour maxima around the equinox in March due to the semi-annual variation can still be detected. Five degrees more polewards this peak can rather hardly be observed. It is notable the water vapour distribution at $25^{\circ} \mathrm{S}$ does not exhibit a minimum around July, that means local winter, as expected from the semi- and annual variation. This behaviour is not as obvious in the Northern Hemisphere but is based on the observation that the phase shift at the subtropical latitudes starts already at an altitude of about $65 \mathrm{~km}$ to $70 \mathrm{~km}$. The water vapour structure at $78 \mathrm{~km}$ and the described characteristics are relatively similar to those at $73 \mathrm{~km}$. As a prominent deviation also the maximum at the equinox at the end of September can be distinguished on both hemispheres. This is even visible at 30 degree latitude. In the Southern Hemisphere clear signatures of the phase shift of the semi-annual variation at that altitude can be observed. This phase shift exists also in tOhe Northern Hemisphere, but is more hidden due to the dominating annual component of the water vapour variation at that latitude. At $83 \mathrm{~km}$ the water vapour distribution shows a semi-annual variation combined with a strong annual component in both hemispheres. As noted before the summer maximum is stronger in the Northern Hemisphere, while the winter maximum is stronger in the Southern Hemisphere. This behaviour is most obvious here, but can easily be observed also at $73 \mathrm{~km}$ and $78 \mathrm{~km}$.

\section{Discussion and summary}

Five years (2002-2006) of Odin/SMR measurements of the mesospheric water vapour distribution in the tropical and sub-tropical region were used to give a general picture of the mesospheric semi-annual oscillation in water vapour. Year to year variability of the MSAO is clearly observable in Fig. 3. This variability is associated with the modulation of the SAO by the quasi-biennial oscillation (Garcia et al., 1997; Mayr 
et al., 1997). A detailed analysis of the inter-annual variability and the signal of the quasi-biennial oscillation signal in mesospheric water vapour distribution measured by Odin/SMR will be the subject of a future study.

Our data set shows distinct signatures of the semi-annual oscillation in the equatorial region in the entire altitude range of interest, namely between $65 \mathrm{~km}$ and $100 \mathrm{~km}$. The most prominent feature is a phase shift in the semi-annual variation, which occurs in the altitude range between approximately $75 \mathrm{~km}$ and $80 \mathrm{~km}$. This feature can also be observed in the temperature distribution, where the transition occurs somewhat higher in altitude (Clancy et al., 1994; Remsberg et al., 2002; Shepherd et al., 2004; Huang et al., 2006). Below this thin transition layer the maxima of the water vapour distribution are found around the equinoxes, while they occur around the solstices above this layer. Noticeable is also that the phase shift is not entirely 180 degrees between these two altitude domains. There seems to be an apparent difficulty to model the observed phase shift of the mesospheric SAO in water vapour. The simulations of WACCM used here for the tidal analysis show a phase shift that starts already at $60 \mathrm{~km}$. Other models, like COMMA-IAP - Cologne Model of the Middle Atmosphere - Institute of Atmospheric Physics in Kühlungsborn, Sonnemann et al. (1998), do not show any phase shift at all (Körner, 2002; Körner and Sonnemann, 2001). In comparison to the HALOE analysis of the mesospheric SAO in water vapour (Jackson et al., 1998, their Fig. 3) the water vapour maxima observed by Odin/SMR occur one month earlier. A recent model study of the SSAO in water vapour by Lelieveld et al. (2007) make a similar observation, when comparing their results to UARS/HALOE data. This is very likely explained by an under-sampling of the HALOE data due to the solar-occultation technique and the UARS orbit. Part of the data are separated by 60 to 80 days and have subsequently over-smoothed onto a 30 day mean grid. The observed phase shift of the semi-annual variation of the water vapour distribution between $76 \mathrm{~km}$ and $80 \mathrm{~km}$ is consistent with the downward propagation of the MSAO in the zonal wind in this altitude range. In general, the mesospheric SAO in water vapour can be associated to vertical and meridional transport, induced by the MSAO in the zonal wind. This comprises downwelling and adiabatic warming starting at the onset of the easterlies on one hand and upward motion with corresponding adiabatic cooling occurring at the onset of the westerlies on the other hand (Hirota, 1980; Garcia et al., 1997). The upper panel of Fig. 7 might indicate that the semi-annual variation in water vapour may partly be based on an additional component which arises from a meridional advection of water vapour from the polar region of the summer hemisphere across the equator, at least above $80 \mathrm{~km}$.

In the equatorial region the amplitude of the mesospheric SAO exhibits a double peak structure with one maximum at $75 \mathrm{~km}$ and another one at $81 \mathrm{~km}$. The mean amplitudes of these peaks are $0.6 \mathrm{ppmv}$ and 0.8 ppmv respectively.
Both amplitudes vary by \pm 0.3 ppmv over the years, as discussed before in terms of inter-annual variability. This observed structure of the SAO amplitude resembles in principle the amplitude pattern observed by UARS/HALOE (Jackson et al., 1998, their Fig. 5). Since their analysis is limited to $80 \mathrm{~km}$ the upper peak can not be observed completely and accordingly the full amplitude is unknown. Furthermore, the minimum between the two maxima is not statistically significant in the UARS/HALOE evaluation (see again their Fig. 5). The amplitude of the lower peak at $75 \mathrm{~km}$ and also the amplitudes observed at the altitudes below are smaller in the HALOE analysis. The authors discuss the possibility of an underestimation based on the aforementioned oversmoothing in time of the HALOE data. The analysis of the Odin/SMR data shows that the amplitude at the node between stratospheric and mesospheric SAO does not decrease to zero and that the node is actually spread out over a broader altitude range between $50 \mathrm{~km}$ and $63 \mathrm{~km}$. Even very high altitudes show a clear SAO signal, being actually strongest above $85 \mathrm{~km}$ in terms of the relative variation of the volume mixing ratio.

With respect to the latitudinal behaviour of the tropical/subtropical MSAO in water vapour we need to distinguish between the two altitude regions, namely below and above $78 \mathrm{~km}$. The amplitude of the SAO below $78 \mathrm{~km}$ decreases towards higher latitudes, reaching a minimum amplitude at about 25 degree latitude. This picture is consistent with the HALOE observations. As before, the amplitudes observed by Odin/SMR are higher than the amplitudes derived from the HALOE observation. The amplitude of the SAO above $78 \mathrm{~km}$ on the other hand does not show any significant variation with latitude. A similar behaviour has been observed for the MSAO in temperature by the WINDII Wind Imaging Interferometer (Shepherd et al., 1993) instrument aboard the UARS satellite (Shepherd et al., 2004). Correspondingly, the amplitude of the mesospheric semi-annual oscillation in water vapour exhibits a single peak structure at latitudes higher than 20 degree. In the Southern Hemisphere the amplitude of the SAO recovers at sub-tropical latitudes below $80 \mathrm{~km}$. This effect has also been observed in the UARS/HALOE analysis of the mesospheric SAO in water vapour (Jackson et al., 1998) and is in agreement with the characteristics of the SAO in the zonal wind (Ray et al., 1998). Also the annual component of the water vapour variation shows clear inter-hemispheric differences in the subtropics with a higher amplitude in the Northern Hemisphere. The minimum amplitude of the annual component is found in the Southern Hemisphere between $5^{\circ} \mathrm{S}$ and $20^{\circ} \mathrm{S}$. The evaluation of the HALOE water vapour data by (Jackson et al., 1998) shows the amplitude minimum at about $5^{\circ} \mathrm{S}$ and thus somewhat more equatorward than for Odin/SMR. The amplitudes of the annual oscillation derived from the UARS/HALOE data are again smaller, as discussed earlier. The observations of latitudinal structure of the annual oscillation by Odin/SMR confirm previous observations based on 
temperature data taken by HALOE (Remsberg et al., 2002) and WINDII (Shepherd et al., 2004). Between $30^{\circ} \mathrm{S}$ and $10^{\circ} \mathrm{N}$ the SAO is the dominant pattern of variability at altitudes up to $80 \mathrm{~km}$. In the altitude range above $90 \mathrm{~km}$ the SAO dominates at all latitudes addressed in this study.

Finally we note that the Odin/SMR measurements also reveal clear seasonal differences between the two hemispheres in the subtropical region. We observe higher water vapour concentrations during summer and lower concentrations during winter in the Northern Hemisphere as compared to the Southern Hemisphere. This observation can be made roughly in the altitude range between $60 \mathrm{~km}$ and $90 \mathrm{~km}$. The reasons behind this observation are most likely due to interhemispheric differences in the underlying dynamical forcing by waves (sources and/or filtering) and beyond of the scope of this paper.

Nevertheless, following the indication that the semiannual variation in water vapour above $80 \mathrm{~km}$ might be partly due to a meridional advection from the summer polar region across the equator (see upper panel of Fig. 7) seasonal inter-hemispheric differences in the subtropics in this altitude region might be anticipated. Recently evidence of an inter-hemispheric coupling between the polar winter stratosphere and polar summer mesosphere has been presented using the mesospheric pole-to-pole circulation as the connecting link (Karlsson et al., 2007; Becker et al., 2004; Becker and Fritts, 2006; Karlsson et al., 2008). These studies suggest a stronger upwelling in the Northern Hemisphere polar summer mesosphere as compared to the Southern Hemisphere, accompanied by a stronger meridional flow towards the Southern Hemisphere winter polar region. This scenario can account for the advection of higher water vapour concentrations towards the Northern Hemisphere subtropics in summer as compared to its southern counterpart. At the same time, this also could account for higher water vapour concentrations in the winter season in the Southern Hemisphere subtropics than in the corresponding latitude range in the Northern Hemisphere. However, it is obvious that more analysis will be needed to understand the observations and these possible coupling mechanisms in detail.

Acknowledgements. Odin is a Swedish-led satellite project funded jointly by the Swedish National Space Board (SNSB), the Canadian Space Agency (CSA), the National Technology Agency of Finland (Tekes) and the Centre National d'Etudes Spatiales (CNES) in France. The Swedish Space Corporation has been the industrial prime constructor. Since April 2007 Odin is a third-party mission of the European Space Agency (ESA). The main author is supported by grants from SNSB. We wish to acknowledge Nicolas Lautié for his early contributions on the implementation of the $557 \mathrm{GHz}$ band retrieval algorithms. The WACCM model has been developed at the National Center for Atmospheric Research (NCAR) in Boulder (Colorado), USA. We are grateful to Rolando Garcia, who kindly provided the data. A special thanks to Charles McLandress from the University of Toronto for valuable comments regarding tides. We also would like to acknowledge Farah Khosrawi and Heiner
Körnich for their helpful comments on the manuscript. Finally we would like to thank the two anonymous reviewers for their valuable comments.

Edited by: P. Hartogh

\section{References}

Baldwin, M. P., Gray, L. J., Dunkerton, T. J., Hamilton, K., Haynes, P. H., Randel, W. J., Holton, J. R., Alexander, M. J., Hirota, I., Horinouchi, T., Jones, D. B. A., Kinnersley, J. S., Marquardt, C., Sato, K., and Takahashi, M.: The quasi-biennial oscillation, Rev. Geophys., 39, 179-230, doi:10.1029/1999RG000073, 2001.

Barath, F. T., Chavez, M. C., Cofield, R. E., Flower, D. A., Frerking, M. A., Gram, M. B., Harris, W. M., Holden, J. R., Jarnot, R. F., and Kloezeman, W. G.: The Upper Atmosphere Research Satellite Microwave Limb Sounder instrument, J. Geophys. Res., 98, 10 751-10 762, 1993.

Baron, P., Merino, F., and Murtagh, D.: Simultaneous retrievals of temperature and volume mixing ratio constituents from nonoxygen Odin Submillimeter Radiometer bands, Appl. Opt., 40, 6102-6110, 2001.

Becker, E., Müllemann, A., Lübken, F.-J., Körnich, H., Hoffmann, P., and Rapp, M.: High Rossby-wave activity in austral winter 2002: Modulation of the general circulation of the MLT during the MaCWAVE/MIDAS northern summer program, Geophys. Res. Lett., 31, L24S03, doi:10.1029/2004GL019615, 2004.

Becker, E. and Fritts, D. C.: Enhanced gravity-wave activity and interhemispheric coupling during the MaCWAVE/MIDAS northern summer program 2002, Ann. Geophys., 24, 1175-1188, 2006, http://www.ann-geophys.net/24/1175/2006/.

Belmont, A. D. and Dartt, D. G.: Semiannual variation in zonal wind from 20 to 65 kilometers at $80^{\circ} \mathrm{N}-10^{\circ} \mathrm{S}$, J. Geophys. Res., 78, 6373-6376, doi:10.1029/JC078i027p06373, 1973.

Bernath, P. F., McElroy, C. T., Abrams, M. C., Boone, C. D., Butler, M., Camy-Peyret, C., Carleer, M., Clerbaux, C., Coheur, P.-F., Colin, R., DeCola, P., DeMazière, M., Drummond, J. R., Dufour, D., Evans, W. F. J., Fast, H., Fussen, D., Gilbert, K., Jennings, D. E., Llewellyn, E. J., Lowe, R. P., Mahieu, E., McConnell, J. C., McHugh, M., McLeod, S. D., Michaud, R., Midwinter, C., Nassar, R., Nichitiu, F., Nowlan, C., Rinsland, C. P., Rochon, Y. J., Rowlands, N., Semeniuk, K., Simon, P., Skelton, R., Sloan, J. J., Soucy, M.-A., Strong, K., Tremblay, P., Turnbull, D., Walker, K. A., Walkty, I., Wardle, D. A., Wehrle, V., Zander, R., and Zou, J.: Atmospheric Chemistry Experiment (ACE): Mission overview, Geophys. Res. Lett., 32, L15S01, doi: 10.1029/2005GL022386, 2005.

Bevilacqua, R. M., Olivero, J. J., and Croskey, C. L.: Mesospheric water vapor measurements from Penn State: Monthly mean observations (1984-1987), J. Geophys. Res., 94, 12 807-12 818, 1989.

Bevilacqua, R. M., Summers, M. E., Strobel, D. F., Olivero, J. J., and Allen, M.: The seasonal variation of water vapor and ozone in the upper mesosphere - Implications for vertical transport and ozone photochemistry, J. Geophys. Res., 95, 883-893, 1990.

Boone, C. D., Nassar, R., Walker, K. A., Rochon, Y., McLeod, S. D., Rinsland, C. P., and Bernath, P. F.: Retrievals for the Atmospheric Chemistry Experiment Fourier-Transform Spectrometer, Appl. Opt., 44, 7218-7231, 2005. 
Burrage, M. D., Hagan, M. E., Skinner, W. R., Wu, D. L., and Hays, P. B.: Long-term variability in the solar diurnal tide observed by HRDI and simulated by the GSWM, Geophys. Res. Lett., 22, 2641-2644, doi:10.1029/95GL02635, 1995.

Carleer, M. R., Boone, C. D., Walker, K. A., Bernath, P. F., Strong, K., Sica, R. J., Randall, C. E., Vömel, H., Kar, J., Höpfner, M., Milz, M., von Clarmann, T., Kivi, R., Valverde-Canossa, J., Sioris, C. E., Izawa, M. R. M., Dupuy, E., McElroy, C. T., Drummond, J. R., Nowlan, C. R., Zou, J., Nichitiu, F., Lossow, S., Urban, J., Murtagh, D., and Dufour, D. G.: Validation of water vapour profiles from the Atmospheric Chemistry Experiment (ACE), Atmos. Chem. Phys. Discuss., 8, 4499-4559, 2008, http://www.atmos-chem-phys-discuss.net/8/4499/2008/.

Carr, E. S., Harwood, R. S., Mote, P. W., Peckham, G. E., Suttie, R. A., Lahoz, W. A., O'Neill, A., Froidevaux, L., Jarnot, R. F., Read, W. G., Waters, J. W., and Swinbank, R.: Tropical stratospheric water vapor measured by the Microwave Limb Sounder (MLS), Geophys. Res. Lett., 22, 691-694, doi:10.1029/ 95GL00626, 1995.

Chandra, S., Jackman, C. H., Fleming, E. L., and Russell, J. M.: The seasonal and long term changes in mesospheric water vapor, Geophys. Res. Lett., 24, 639-642, doi:10.1029/97GL00546, 1997.

Chapman, S. and Lindzen, R. S.: Atmospheric tides, D. Reidel Publishing, Norwell, Massachusetts, USA, 1970.

Clancy, R. T., Rusch, D. W., and Callan, M. T.: Temperature minima in the average thermal structure of the middle mesosphere $(70-80 \mathrm{~km})$ from analysis of $40 \mathrm{~km}$ to $92 \mathrm{~km}$ SME global temperature profiles, J. Geophys. Res., 99, 19001-19020, doi: 10.1029/94JD01681, 1994.

Delisi, D. P. and Dunkerton, T. J.: Seasonal variation of the semiannual oscillation, J. Atmos. Sci., 45, 2772-2809, 1988.

Dunkerton, T. J.: Theory of the mesopause semiannual oscillation, J. Atmos. Sci., 39, 2681-2690, 1982.

Efron, B.: Bootstrap methods: Another look at the jackknife, Ann. Stat., 7, 1-26, 1979.

Forbes, J. M.: Tidal and planetary waves, The upper mesosphere and lower thermosphere: A review of experiment and theory, Geophys. Monogr., 87, 67 pp., 1995.

Frisk, U., Hagström, M., Ala-Laurinaho, J., Andersson, S., Berges, J.-C., Chabaud, J.-P., Dahlgren, M., Emrich, A., Florén, H.-G., Florin, G., Fredrixon, M., Gaier, T., Haas, R., Hirvonen, T., Hjalmarsson, Å., Jakobsson, B., Jukkala, P., Kildal, P. S., Kollberg, E., Lassing, J., Lecacheux, A., Lehikoinen, P., Lehto, A., Mallat, J., Marty, C., Michet, D., Narbonne, J., Nexon, M., Olberg, M., Olofsson, A. O. H., Olofsson, G., Origné, A., Petersson, M., Piironen, P., Pons, R., Pouliquen, D., Ristorcelli, I., Rosolen, C., Rouaix, G., Räisänen, A. V., Serra, G., Sjöberg, F., Stenmark, L., Torchinsky, S., Tuovinen, J., Ullberg, C., Vinterhav, E., Wadefalk, N., Zirath, H., Zimmermann, P., and Zimmermann, R.: The Odin satellite. I. Radiometer design and test, Astron. Astrophys., 402, L27-L34, doi:10.1051/0004-6361:20030335, 2003.

Garcia, R. R., Dunkerton, T. J., Lieberman, R. S., and Vincent, R. A.: Climatology of the semiannual oscillation of the tropical middle atmosphere, J. Geophys. Res., 102, 26019-26032, doi:10.1029/97JD00207, 1997.

Garcia, R. R., Marsh, D. R., Kinnison, D. E., Boville, B. A., and Sassi, F.: Simulation of secular trends in the middle atmosphere, 1950-2003, J. Geophys. Res., 112, D09301, doi:
10.1029/2006JD007485, 2007.

Groves, G. V.: Annual and semi-annual zonal wind components and corresponding temperature and density variations, $60 \mathrm{~km}-$ 130 km, Planet. Space Sci., 20, 2099-2112, 1972.

Hamilton, K.: Rocketsonde observations of the mesospheric semiannual oscillation at Kwajalein, Atmos.-Ocean, 20, 281-286, 1982.

Hamilton, K., John Wilson, R., Mahlman, J. D., and Umscheid, L. J.: Climatology of the SKYHI troposphere stratosphere mesosphere general circulation model, J. Atmos. Sci., 52, 5-43, doi: 10.1175/1520-0469(1995)052, 1995.

Hirota, I.: Observational evidence of the semiannual oscillation in the tropical middle atmosphere - A review, Pure Appl. Geophys., 118, 217-238, 1980.

Hitchman, M. H. and Leovy, C. B.: Evolution of the zonal mean state in the equatorial middle atmosphere during October 1978May 1979, J. Atmos. Sci., 43, 3159-3176, 1986.

Hitchman, M. H. and Leovy, C. B.: Estimation of the Kelvin wave contribution to the semiannual oscillation, J. Atmos. Sci., 45, 1462-1475, 1988.

Holton, J. R. and Wehrbein, W. M.: A numerical model of the zonal mean circulation of the middle atmosphere, Pure Appl. Geophys., 118, 284-306, 1980.

Huang, F. T., Mayr, H. G., Reber, C. A., Russell, J. M., Mlynczak, M., and Mengel, J. G.: Stratospheric and mesospheric temperature variations for the quasi-biennial and semiannual (QBO and SAO) oscillations based on measurements from SABER (TIMED) and MLS (UARS), Ann. Geophys., 24, 2131-2149, 2006, http://www.ann-geophys.net/24/2131/2006/.

Jackson, D. R., Burrage, M. D., Harries, J. E., Gray, L. J., and Russell, J. M.: The semi-annual oscillation in upper stratospheric and mesospheric water vapour as observed by HALOE, Q. J. Roy. Meteor. Soc., 124, 2493-2515, doi:10.1256/smsqj.55115, 1998.

Karlsson, B., Körnich, H., and Gumbel, J.: Evidence for interhemispheric stratosphere-mesosphere coupling derived from noctilucent cloud properties, Geophys. Res. Lett., 34, L16806, doi: 10.1029/2007GL030282, 2007.

Karlsson, B., McLandress, C., and Shepherd, T. G.: Interhemispheric mesospheric coupling in a comprehensive middle atmosphere model, J. Atmos. Sol.-Terr. Phys., under review, 2008.

Körner, U. and Sonnemann, G. R.: Global three-dimensional modeling of the water vapor concentration of the mesospheremesopause region and implications with respect to the noctilucent cloud region, J. Geophys. Res., 106, 9639-9652, doi: 10.1029/2000JD900744, 2001.

Körner, U.: Global three-dimensional modelling of minor constituents in the middle atmosphere including the hydrogen escape flux, Ph.D. thesis, Leibniz-Institut für Atmosphärenphysik in Kühlungsborn/Universität Rostock, Germany, 2002.

Lambert, A., Read, W. G., Livesey, N. J., Santee, M. L., Manney, G. L., Froidevaux, L., Wu, D. L., Schwartz, M. J., Pumphrey, H. C., Jimenez, C., Nedoluha, G. E., Cofield, R. E., Cuddy, D. T., Daffer, W. H., Drouin, B. J., Fuller, R. A., Jarnot, R. F., Knosp, B. W., Pickett, H. M., Perun, V. S., Snyder, W. V., Stek, P. C., Thurstans, R. P., Wagner, P. A., Waters, J. W., Jucks, K. W., Toon, G. C., Stachnik, R. A., Bernath, P. F., Boone, C. D., Walker, K. A., Urban, J., Murtagh, D., Elkins, J. W., and Atlas, E.: Validation of the Aura Microwave Limb Sounder middle atmosphere water vapor and nitrous oxide measurements, J. Geophys. Res., 
112, D24S36, doi:10.1029/2007JD008724, 2007.

Lautié, N., Urban, J., Baron, P., Eriksson, P., Jiménez, C., de la Noë, J., Le Flochmoën, E., Merino, F., Murtagh, D., Olberg, M., and Ricaud, P.: Retrieval of trace gas profiles from Odin/SMR limb measurements: non-linear retrieval scheme for $\mathrm{H}_{2} \mathrm{O}$ at 556.9 GHz, pp. 93 - 105, International Symposium on Submillimeter Wave Earth Observation from Space - III, 8-9 October 2001, Delmenhorst, Germany, Logos Verlag, Berlin, 93-105, 2001.

Lelieveld, J., Brühl, C., Jöckel, P., Steil, B., Crutzen, P. J., Fischer, H., Giorgetta, M. A., Hoor, P., Lawrence, M. G., Sausen, R., and Tost, H.: Stratospheric dryness: Model simulations and satellite observations, Atmos. Chem. Phys., 7, 1313-1332, 2007, http://www.atmos-chem-phys.net/7/1313/2007/.

Lossow, S., Urban, J., Eriksson, P., Murtagh, D., and Gumbel, J.: Critical parameters for the retrieval of mesospheric water vapour and temperature from Odin/SMR limb measurements at $557 \mathrm{GHz}$, Adv. Space Res., 40, 835-845, 2007.

Mayr, H. G., Mengel, J. G., Hines, C. O., Chan, K. L., Arnold, N. F., Reddy, C. A., and Porter, H. S.: The gravity wave Doppler spread theory applied in a numerical spectral model of the middle atmosphere. 2. Equatorial oscillations, J. Geophys. Res., 102, 26093-26 106, doi:10.1029/96JD03214, 1997.

McLandress, C.: Seasonal variability of the diurnal tide: Results from the Canadian Middle Atmosphere General Circulation Model, J. Geophys. Res., 102, 29747-29764, doi:10.1029/ 97JD02645, 1997.

Meyer, W. D.: A diagnostic numerical study of the semiannual variation of the zonal wind in the tropical stratosphere and mesosphere, J. Atmos. Sci., 27, 820-830, 1970.

Nedoluha, G. E., Bevilacqua, R. M., Michael Gomez, R., Waltman, W. B., Hicks, B. C., Thacker, D. L., and Andrew Matthews, W.: Measurements of water vapor in the middle atmosphere and implications for mesospheric transport, J. Geophys. Res., 101, 21 183-21 194, doi:10.1029/96JD01741, 1996.

Randel, W. J., Wu, F., Russell, J. M., Roche, A., and Waters, J. W.: Seasonal cycles and QBO variations in stratospheric $\mathrm{CH}_{4}$ and $\mathrm{H}_{2} \mathrm{O}$ observed in UARS HALOE data, J. Atmos. Sci., 55, 163$185,1998$.

Ray, E. A., Alexander, M. J., and Holton, J. R.: An analysis of the structure and forcing of the equatorial semiannual oscillation in zonal wind, J. Geophys. Res., 103, 1759-1774, doi:10.1029/ 97JD02679, 1998.

Reed, R. J. and Rogers, D. G.: The circulation of the tropical stratosphere in the years 1954-1960, J. Atmos. Sci., 19, 127-135, 1962.

Reed, R. J.: Zonal wind behavior in the equatorial stratosphere and lower mesosphere, J. Geophys. Res., 71, 4223-4233, 1966.

Remsberg, E. E., Bhatt, P. P., and Deaver, L. E.: Seasonal and longer-term variations in middle atmosphere temperature from HALOE on UARS, J. Geophys. Res., 107, ACL 18-1 pp., CiteID 4411, doi:10.1029/2001JD001366, 2002.
Rodgers, C. D.: Inverse methods for atmospheric soundings: Theory and practice, ISBN 981-02-2740-X, World Scientific Publishing Co. Pte. Ltd., 2000.

Russell, J. M., Gordley, L. L., Park, J. H., Drayson, S. R., Hesketh, W. D., Cicerone, R. J., Tuck, A. F., Frederick, J. E., Harries, J. E., and Crutzen, P. J.: The Halogen Occultation Experiment, J. Geophys. Res., 98, 10777-10 797, 1993.

Sassi, F. and Garcia, R. R.: The role of equatorial waves forced by convection in the tropical semiannual oscillation, J. Atmos. Sci., 54, 1925-1942, 1997.

Shepherd, G. G., Thuillier, G., Gault, W. A., Solheim, B. H., Hersom, C., Alunni, J. M., Brun, J. F., Brune, S., Charlot, P., Cogger, L. L., Desaulniers, D. L., Evans, W. F. J., Gattinger, R. L., Girod, F., Harvie, D., Hum, R. H., Kendall, D. J. W., Llewellyn, E. J., Lowe, R. P., Ohrt, J., Pasternak, F., Peillet, O., Powell, I., Rochon, Y., Ward, W. E., Wiens, R. H., and Wimperis, J.: WIND II, the WIND imaging interferometer on the Upper Atmosphere Research Satellite., J. Geophys. Res., 98, 10 725-10 750, 1993.

Shepherd, M. G., Evans, W. F. J., Hernandez, G., Offermann, D., and Takahashi, H.: Global variability of mesospheric temperature: Mean temperature field, J. Geophys. Res., 109, $24117-$ D24117, doi:10.1029/2004JD005054, 2004.

Sonnemann, G. R., Kremp, C., Ebel, A., and Berger, U.: A threedimensional dynamic model of the minor constituents of the mesosphere, Atmos. Environ., 32, 3157-2172, 1998.

Torrence, C. and Compo, G.: A practical guide to wavelet analysis, Bull. Am. Meteorol. Soc., 79, 61-78, 1998.

Urban, J., Lautié, N., Murtagh, D., Eriksson, P., Kasai, Y., Lossow, S., Dupuy, E., de La Noë, J., Frisk, U., Olberg, M., Le Flochmoën, E., and Ricaud, P.: Global observations of middle atmospheric water vapour by the Odin satellite: An overview, Planet. Space Sci., 55, 1093-1102, doi:10.1016/j.pss.2006.11. 021, 2007.

Vincent, R. A., Tsuda, T., and Kato, S.: A comparative study of mesospheric solar tides observed at Adelaide and Kyoto, J. Geophys. Res., 93, 699-708, 1988.

Waters, J. W., Froidevaux, L., Harwood, R. S., Jarnot, R. F., Pickett, H. M., Read, W. G., Siegel, P. H., Cofield, R. E., Filipiak, M. J., Flower, D. A., Holden, J. R., Lau, G. K., Livesey, N. J., Manney, G. L., Pumphrey, H. C., Santee, M. L., Wu, D. L., Cuddy, D. T., Lay, R. R., Loo, M. S., Perun, V. S., Schwartz, M. J., Stek, P. C., Thurstans, R. P., Boyles, M. A., Chandra, K. M., Chavez, M. C., Chen, G.-S., Chudasama, B. V., Dodge, R., Fuller, R. A., Girard, M. A., Jiang, J. H., Jiang, Y., Knosp, B. W., Labelle, R. C., Lam, J. C., Lee, A. K., Miller, D., Oswald, J. E., Patel, N. C., Pukala, D. M., Quintero, O., Scaff, D. M., Vansnyder, W., Tope, M. C., Wagner, P. A., and Walch, M. J.: The Earth Observing System Microwave Limb Sounder (EOS MLS) on the Aura Satellite, IEEE T. Geosci. Remote, 44, 1075-1092, doi: 10.1109/TGRS.2006.873771, 2006.

Webb, W. L.: Structure of the stratosphere and mesosphere, Academic Press, New York and London, 1966. 